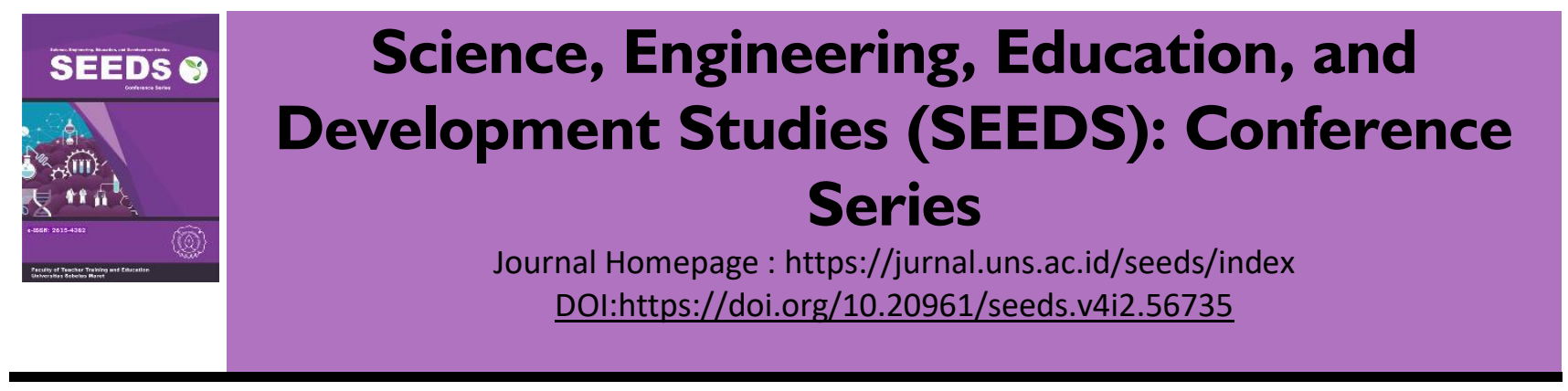

\title{
PENGGUNAAN MEDIA VIDEO PEMBELAJARAN DAN POWER POINT DALAM MATA PELAJARAN TIK KELAS VII DI SMP NEGERI 1 GURAH
}

\author{
Sri Astutik
}

UPTD SMP NEGERI 1 Gurah, Kabupaten Kediri, awa Timur ibututikcantik76@gmail.com

Article Info :

Available online 24 Nopember 2020

\section{Keywords:}

learning media

learning video

power point

ICT lesson

\begin{abstract}
Along with the rapid development of technology causing students to be more proficient in using gadgets, for this reason, here the author wants to determine that this literature review has the following objectives; (1) understanding of learning video media (2) understanding of power point media; (3) what are the benefits of learning video media; (4) is expected to know the benefits of power point media. This discussion uses a variety of literature approach. The expected results of this discussion are to gain an understanding of; 1) By utilizing learning video media and power points, students are expected to be more active and creative in learning; 2) By utilizing this learning video and power point media, with hoped that students will be able to witness an event where the event cannot be witnessed directly, as well as past events that cannot be brought directly into the classroom. Students can also play back the videos that have been obtained according to their respective needs and needs. Learning activities that use video media can foster interest and motivate students to always try to pay attention to lessons. 3) Learning video media and power point are learning media that are very appropriate and accurate in delivering messages and helping students to understand and knowing them. By using instructional video media and power points, students know and understand more about the material that is being delivered by educators, either through the screening of a film that is shown or a power point being presented.
\end{abstract}




\section{PENDAHULUAN}

Teknologi informasi dan komunikasi saat ini berkembang semakin pesat seiring dengan tuntutan kebutuhan dan gaya hidup dalam masyarakat. Hal ini dapat kita amati dari semakin merebaknya penggunaan smartphone pada semua kalangan masyarakat, mulai dari masyarakat dengan tingkat ekonomi lemah, hingga mereka yang notabene mempunyai kehidupan mapan, demikian juga mulai dari kalangan orang dewasa hingga kalangan remaja dan anak-anak. Smartphone sudah dianggap kebutuhan primer yang wajib dipenuhi untuk mendukung kegiatan dan aktivitas sehari-hari. Berdasarkan hasil penelitian dari Chuzaimah Mabruroh dan Fereshti Nurdiana Dihan (2015) diperoleh hasil penelitian yang menimbulkan persepsi bahwa smartphone menjadi gaya hidup yang paling dominan dibandingkan dengan kebutuhan dan keinginan yang dianggap tidak penting.

Penggunaan smartphone sendiri menunjukkan banyak keuntungan bagi yang menggunakannya, diantaranya di bidang pembelajaran dapat digunakan sebagai media pembelajaran terutama bidang komunikasi sampai pada tingkat sarana pembelajaran informasi. Contohnya untuk mengubah pembelajaran menjadinlebih efektif, dan edukatif secara modern dan tepat guna. Smartphone juga bisa digunakan untuk mengakses internet terutama untuk mencari informasi lebih mudah dan lebih cepat mendapatkannya dengan sebanyak-banyaknya, Mencari informasi dapat dilakukan dengan hanya klik Smartphone dari manapun dan dikesempatan apapun tanpa harus memperhitungkan waktu,sehingga diperoleh informasi yang lengkap mengenai Ilmu pengetahuan, Teknologi ataupun berita lainnya, dan siswa akan merasa lebih mudah dalam mencari dan mengakses informasi yang berkaitan dengan materi dan tugas dari sekolah dari berbagai sumber di internet.

- Sesuai dengan kenyataan yang ada di lapanganbahwa hanya sebagian kecil peserta didik yang menggunakan Smartphone sebagai alat untuk meningkatkan kemampuan pengetahuan ataupun ketrampilan, padahal seperti yang kita tahu bahwa dengan smartphone peerta didik dapat memperoleh pengetahuan yang sebanyak-banyaknya baik. Sebagian besar dari mereka menggunakan smartphone hanya untuk memenuhi tuntutan gaya hidup yang ingin dianggap modern. Dengan perkembangan Informasi dan komunikasi yang sangat pesatnya, sehingga Mata pelajaran Teknologi Informasi dan Komunikasi yang semula wajib ada di Kelompok Mata pelajaran mulai pemberlakuan Kurikulum 13 Pelajaran TIK (Teknologi Informasi dan Komunikasi berubah menjadi Kelompok Bimbingan dimana inklud di semua mata pelajaran, juga pertemuan tatap muka dengan siswa juga hanya diberi kesempatan satu jam tatap muka. Juga di latar belakangi kelas VII yang notabene dari Sekolah Dasar (SD) belum pernah mendapatkan Pelajaran Teknologi Informasi dan Komunikasi sehingga menuntut pendidik untuk mencari metode atau media pembelajaran yang menarik untuk mengenalkan Teknologi Informasi dan Komunikasi ke pada siswa Kelas VII agar peserta didik menjadi tertarik untuk mempelajari apakah itu Pelajaran Tekologi Informasi dan Komunikasi.

Sebelum kita membahas lebih dalam tentang apa itu Media Pembelajaran, marilah kita mengenal dulu apa itu Media?. Secara umum pengertian dari Media adalah suatu alat perantara yang dapat menghubungkan atau sebagai perantara informasi atau sumber berita dengan penerima informasi atau orangnya. Sedangkan menurut pendapat dari Smaldino dan kawan-kawan (2004), media adalah alat atau sarana komunikasi. Sedangkan Palazon, (2000), berpendapat bahwa Media sebagai segala bentuk peralatan komunikasi baik berupa simbol, alat produksi, ataupun distribusi yang ada di masuarakat pada umumnya. Menurut pendapat Yaumi (2017) bahwa segala macam bentuk peralatan baik itu berupa audio, cetak, video, objek, visal, dan orangnya itu sendiri dinamakan sebagai Media.

Berikutnya untuk peningkatan mutu pembelajaranyang merupakan salah satu bentuk paradigma atau pemikiran baru pendidikan, maka sebagai pendidik kita harus berusaha untuk berinovasi mengembangkan media pembelajaran sesuai dengan kebutuhan /tuntutan jaman dan menyesuaikan dengan visi pendidikan secara global atau luas. Media pembelajaran juga merupakan salah satu bagian inti dari proses pembelajaran itu sendiri, yaitu sebagai alat untuk membantu mempercepat pemahaman peserta didik akan materi suatu pembelajaran dan dengan media pembelajaran yang menarik serta interaktif dapat meningkatkan hasil belajar yang konkrit atau nyata.

Berdasarkan masalah di atas, diperlukan inovasi pembelajaran, Disini penulis memilih media Video Pembelajaran dan power point digunakan untuk meningktkan hasil belajar siswa pada pembelajaran Teknologi Informasi dan Komunikasi di Kelas VII pada SMPN 1 Gurah. 


\section{PEMBAHASAN}

\section{Pengertian Media Pembelajaran}

Secara umum pengertian dari media pembelajaran merupakan suatu alat untuk membantu agar terjadinya proses kegiatan belajar dan mengajar, juga dapat diartikan bahwa media pembelajaran merupakan semua peralatanm yang dapat dimanfaatkan untuk menumbuhkan rangsangan baik itu berupa perhatian, perasaan, kemampuan, pikiran ataupun keterampilan dari peserta didik sehingga bsa terwujudnya suatu proses pembelajaran. Secara luas media pembelajaran dapat meliputi sumber belajarnya, metode yang sigunakan, lingkungan sosialnya, peserta didik dan pendidiknya, agar tercapai tujuan dari proses pembelajaran. Menurut pendapat Briggs dalam Ekayani (2017), pengertian dari media pembelajaran yaitu prasarana yang nyata, bisa berupa film, video, buku yang digunakan untuk menyampaikan materi dan isi dalam pembelajaran. Pendapat dari National Education Associaton dalam Ekayani (2017), media pembelajaran merupakan semua sarana untuk berkomunikasi menyampaikan materi dalam bentuk pandang dengar, ataupun cetak, yang di dalamnya ada teknologi Hardware atau perangkat keras juga ada media pembelajaran itu sendiri. Sedangkan Wingkel 2004:11, berpendapat bahwa media pembelajaran adalah proses penyampaian pesan kepada seseorang /penerima pesan dalam kegiatan pembelajaran yang saat itu berlangsung dengan cara menggunakan alat, proses, ataupun cara yang tepat.

Media Pembelajaran juga bisa dianggap sebagai alat atau sarana dalam penyampaian pesan dari seseorang pengirim kepada seorang penerima, dengan harapan. Sudjana dan Rivai dalam Indrastyawati, dkk (2013:2), berpendapat bahwa media pembelajaran dapat mengakibatkan hasil belajar peserta didik jadi meningkay, yaitu :

1. Motivasi belajar dapat tumbuh dengan adanya pengajaran yang menarik perhatian bagi peserta didik;

2. Peserta didik lebih memahami dan lebih menguasai tujuan pembelajaran yang disampaikan oleh pendidik dengan materi pelajaran yang bermakna;

3. Dengan pemilihan metode pembelajaran yang inovatif dan variatif serta kreatif tidak hanya kata-kata dari pendidik saja, sehingga dapat meningkatkan semangat, motivasi dan keinginan peserta didik dalam belajar, dan peserta didik tidak merasa bosan.

4. Peserta didik tidak hanya dapat mendengar ceramah dari pendidik, tetapi lebih banyak aktivitas belajar diantaranya, mengobservasi, mengamati, menganalisa, mendemonstrasikan, dan berkomunikasi dengan siswa lainnya dalam pembelajaran diskusi kelompok.

Dari bebrapa pendapat yang sudah diuraikan di atas kita bisa menarik kesimpulan bahwa: media merupakan alat yang dipakai untuk mendukung suatu kegiatan pembelajaran, dimana kegiatan tersebut dapat dilaksanakan dengan sebaik baiknya. Media juga bisa dikatakan sebagai sarana agar terjadi interaksi antara pemberi informasi dan penerimanya, sehngga tercipta sebuah kegiatan pembelajaran. Jadi materi yang akan disampaikan oleh pendidik dan yang akan dipelajrai oleh peserta didik dapat terjadi jika ada sarana media.

Sedangkan media pembelajaran itu sendiri merupakan semua sarana atau alat bantu dalam pelaksanaan proses pembelajaran, yang sangat penting dan sangat dibutuhkan sehingga dapat meningkatkan hasil prestasi peserta didik juga dapat merangsang tumbuhnya daya pikir, perhatian, perasaan, serta kemampuan keterampilan peserta didik yang dapat menimbulkan kegiatan proses belajar.

\section{Pengertian Video Pembelajaran}

Menurut Cheppy Riyana (2007), media video pembelajaran adalah segala sesuatu yang dapat digunakan untuk menyampaikan materi pembelajaran baik itu yang berupa audio atau visual, dimana di dalamnya terdapat banyak pesan pembelajaran baik itu teori, pengetahuan, konsep materi, perinsip pembelajaran ataupun prosedur dan langkah-langkah yang harus dilaksanakan agar tercapai tujuan pembelajaran. Sedangkan video itu sendiri memiliki pemahaman sebagai bahan pembelajaran yang berisi materi/pesan yang akan disampaikan kepada peserta didikyang tampk dan dengar (audio visual). Menurut pendapat Sungkono 2003:65, vidio adalah sarana yang berisi materi/bahan ajar yang dikemas sehingga dapat di dengar dan dilihat melalui VCD player berupa pita video.

Menurut Arsyad dalam Winarto 2016:136, video terdiri dari beberapa frame yang diproyeksikan dengan proyektor pada layar secara mekanis sehingga tampak gambar hidup. Menurut Daryanto dalam Komar (2018), menyatakan bahwa video adalah salah satu bahan pembelajaran non cetak yang disampaikan kepada 
peserta didik dengan langsung melihat pada layar yang penuh dengan informasi dan disampaikan secara lugas di hadapan peserta didik.

Pendapat dari Cheppy Riyana (2007:6), media video pembelajaran itu sebagai sarana penyampaian bahan atau materi pembelajaran dengan tujuan :

1) Dapat menjelaskan dan memudahkan penyampaian materi atau pesan dengan makna yang jelas;

2) Dapat mengatasi masalah kurangnya waktu, kurangnya kemampuan melihat pesrta didik, maupun pendidik dan kurangnya ruang gerak;

3) Dapat dipakai dengan tepat dan banyak variasi yang digunakan disesuaikan dengan materi dan bahan yang ingin di sampaikan pada peserta didik.

Menurut (Alphaomegaproperty, 2020) video adalah gambar gerak yang terdapat seragkaian alur dan menampilkan pesan dari bagian sebuah gambar untuk tercapainya tujuan pembelajaran.

Dari pembahasan di atas dapat disimpulkan Video pembelajaran dapat diartikan bahwa suatu alat atau sarana yang dibuat sedemikian rupa agar dapat menarik dan tetap berpedoman pada kurikulum yang sedang digunakan atau berlaku saat itu dalam pengembanganya, dengan mengaplikasikan kaedah pembelajaran yang sistematis, sehingga peserta didik dapat lebih memahami dan mengerti serta dapat mencermati materi yang disampaikan oleh pendidik dengan mudah. Dalam pengunaan media pembelajaran berbasis video juga harus dapat menyiapkan infrastruktur yang memadai.

\section{Manfaaat Media Video pembelajaran}

Menurut Aqib (2013:51), manfaat dari media video pembelajaran adalah:

1) Proses belajar dapat lebih menarik dan lebih jelas;

2) Pembelajaran menjadi saling berhubungan;

3) Lebih efisien baik tenaga dan waktunya;

4) Hasil pembelajaran menjadi berkuaitas;

5) Pelaksanaan pembelajaran bisa kapan saja dan darimana saja;

6) Materi pembelajaran dan proses pembelajaran dapat ditumbuhkan dengan sikap positif dalam pembelajaran;

7) Pendidik memiliki peningkatan peran baiksecara produktif dan positif.

Sedangkan menurut Rusman (2012:220) kelebihan dari media video pembelajaran:

1) Peserta didik dapat menerima pesan melalui video dengan merata;

2) Untuk menerangkan suatu proses dengan menggunakan video jadi lebih menarik;

3) Video dapat di putar atau di hentikan disesuaikan dengan kebutuhan sehingga waktu dan ruang yang terbatas dapat diatasi;

4) Sikap siswa dapat dipengaruhi oleh penyampaian pesan yang terlalu dalam

Jadi dapat disimpulkan bahwa secara umum agar penyampaian materi atau pesan kepada peserta didiknya dapat lebih mudah dimengerti dan menarik maka pendidik dapat menggunakan media video pembelajaran dengan menampilkan gambar, suara, dena gerak yang menarik dan variatif

\section{Pengertian Media power point}

Menurut Hujair (2009: 127-128), media power point merupakan salah satu program apikasi bagian dari Microsoft Office yang berupa prentasi dalam penampilanya menggunakan bantuan layar dan LCD proyektor sehingga dapat dilihat oleh peserta didik. Pengertian media power point secara umum adalah bagian dari aplikasi Microsoft Office, yang menampilkan banyak slide dalam presentasinya pada peserta didik baik dengan kompleks ataupun sederhana.

Penggunan media power point sangat mudah karna banyak template atau desain yang disiapkan dalam membuat tampilan, agar presentasi jadi semakin menarik, biasanya dipakai para pengusaha untuk mempromosikan usahanya, dipakai guru untuk menyampaikan materi pemblajaran, digunakan untuk pelajar atau mahasiswa untuk mempresentasikan tugasnya

Jelita 2010, Microsoft power point merupakan program yang dapat menampilkan presentasi dengan profesional, efective dan lebih mudah. Dengan media power point dapat menyampaikan ide atau gagasan 
menadi lebih jelas dan lebih menarik tujuan untuk dipelajari, karena media ini sangat mudah ditampilkan dengan layar monitor komputer, baik pembuatan presentasi elektronik, dinamis, outline, ataupun slide. Media power point sangat membantu dalam mempresentasikan suatu penjelasan yang masih ragu-ragu atau belum dipahami betul-betul. Dengan media power point pembaca jadi lebih mudah menerima penjelasan dan lebih mengerti dari materi yang disampaikan karena terangkum secara menarik dan ringkas, dalam slide yang tidaak terlalu banyak kalimat, tapi gambar. Audio dan kalimat penjelaan yang secukupnya.

Dari beberapa pengertian di atas dapat disimpulkan bahwa Media powerpoint adalah program aplikasi yang masuk dalam kategori multimedia yang menarik, dan bagian dari program Microsoft office dalam bentuk presentasi dengan menanmpilkan teks, video, gmbar yang menarik dan mudah dipahami. Dengan powerpoint pendidik jadi lebih mudah dalam menyampaikan informasi dan tujuan pembelajaran kepada peserta didik

\section{Manfaaat Media Power Point}

Dengan kemajuan jaman semakin modern sehingga perkembangan TIK juga mengalami kemajuan yang pesat, banyak sekali aplikasi tersedia guna menunjang kegiatan belajar mengajar. Yang dimulai dari tahap pendahuluan atau persiapan,tahap pelaksanaan sampai dengan tahap penilaian atau evaluasi dan terakhir adalah pelaporan kegiatan belajar mengajar, saat ini diberi kemudahkan dengan hadirnya bemacam-macam aplikasi digital. Salah satu contohnya yang sudah sangat populer digunakan oleh guru saat mengajar adalah penggunaan media power point. Menurut Daryanto dalam Komar (2016) beberapa manfaat dari teknologi berbasis Multimedia yakni Media Power Point adalah sebagai berikut:

1. Penerima Pesan dapat lebih memperhatikan materi yang disampaikan karena tampilan yang lebih menarik.

2. Penerima Pesan lebih mudah dalam mengingat materi yang diberikan.

3. Informasi yang disampaikan lebih mudah karena sudah tertata didalam slide.

4. Proses komunikasi yang terjadi tidak membosankan karena lebih interaktif dan menarik.

Dengan demikian Media power point sangat bermanfaat bagi peserta didik maupun pendidik dalam kegiatan pembelajaran baik secara Daring maupun Luring media power point tetap memiliki manfaat yang besar.

\section{Mengenal Pelajaran TIK}

Kemdikbud, menguraikan bahwa teknologi informasi dan komunikasi (TIK) dapat memuat semua teknologi yang berhubungan dengan penanganan informasi. Menurut Budiana, Sjafirah, dan Bakti (2015), TIK adalah semua teknologi yang berhubungan dengan pengambilan, pengumpulan (akuisisi), pengolahan, penyimpanan, penyebaran, dan penyajian informasi.

Kurikulum Tingkat Satuan Pendidikan (KTSP) jmulai diberlakukan sejak tahun 2004 dimana telah merubah sistem pembelajaran menjadi berorientasi pada siswa, Disinilah mata pelajaran menjadi aspek perhatian yang lebih. Dimana sebelumnya guru sebagai satu-satunya sumber belajar siswa, tetapi kini hanya menjadi fasilitator dan motivator. Siswa dituntuk untuk lebih aktif mencari informasi dari berbagai sumber, dengan harapan, pengetahuan siswa menjadi lebih luas dan beragam. untuk menghadapi tuntutan kurikulum tersebut, perlu adanya pemilihan media pembelajaran yang tepat guna mencapai keberhasilan dalam proses belajar mengajar. Hal inilah yang menyebabkan peranan media tidak hanya sebagai alat bantu semata bagi para guru dalam melaksanakan proses belajar mengajar, media pembelajaran juga berperan sebagai alat penyalur pesan dari pemberi pesan (guru, penulis buku, produser dan sebagainya) ke penerima pesan (siswa/ pelajar). Pada Tahun 2013 mata pelajaran TIK hilang dari kelompok mapel utama pada Kurikulum 13 berubah tidak lagi menjadi mata pelajaran wajib tetapi berubah masuk menjadi kelompok bmbingan. Sejak Tahun 2020 keluarlah Permendikbud yang menunjuk beberapa sekolah boleh menerapkan mata pelajaran Informatika tetapi hanya di beberapa sekolah saja. Setelah itu belum ada lagi peraturan tambahan yang mengatur tentang mata pelajaran TIK.

Dengan adanya penemuan dibidang Rekayasa material mikroelektronika menunjukkan perkembangan TIK (Teknologi Informasi dan Komunikasi) diabad ke-21 ini, dengan demikian dapat mempengaruhi segala aspek kehidupan dalam segala hal baik kegiatan atau aktivitas bahkan perilaku kita. Jadi untuk menyiapkan peserta didik yang mampu menghadapi perkembangan abad ke-21 ini maka mata pelajaran TIK sangat diperlukan walaupun sekarang masuk dalam kelompok Bimbingan. 
Dari uraian di atas dapat kita simpulkan bahwa media pembelajaran TIK (Teknologi Informasi dan Komunikasi) dapat diajarkan sebagai mata pelajaran bimbingan yang mungkin penyampaian bisa langsung inklud di semua mata pelajaran atau terpisah. Dalam kehidupan sehari-hari TIK (Teknologi Informasi dan Komunikasi) sangat berperan dalam segala bidang terutama dibidang pendidikan, selalu memanfaatkan TIK untuk kegiatan belajar mengajar.

Dari beberapa contoh penelitian yang telah dilaksanakan diperoleh hasil sebagai berikut :

1. Mengutip kesimpulan dari penelitian Busyaeri dan Udin (2016) : Penggunaan Media video pembelajaran pada mata pelajaran IPA ternyata sangat diminati oleh .semua siswa MIN Kroya, dengan bukti yang diperoleh hasil penelitian yang dilakukan dengan responden sejumlah 27 siswa sebagai sampelnya, sebesar 79,634\% setuju dengan penerapan video pembelajaran pada materi alat pencernaan manusia, ada $12.962 \%$ yang tidak setuju penggunaan media video pembelajaran dan $7,404 \%$ yang menjawab raguragu.

2. Mengutip Kesimpulan dari penelitian Misbahudin, dkk (2018) : PENGGUNAAN POWER POINT SEBAGAI MEDIA PEMBELAJARAN: EFEKTIFKAH?

Dari hasil penelitian yang mnggunakan Metode desktiptif dengan jumlah responden kelas 8B MTS ArRosyidiyah kota Bandung dengan jumlah 27 orang dengan menggunakan Media Power Point pada pembelajaran IPA dapat diukur efektivitas pembelajarannya, dan diperoleh hasil : 1) peserta didik lebih mengerti dan memahami materi yang disampaikan oleh pendidik; 2) peserta didik lebih aktif dan konsentrasi dalam pembelajaran; 3) rencana pembelajaran dapat tersampaikan secara maksimal.

\section{KESIMPULAN}

Dari hasil deskripsi ini dapat disimpulkan bahwa media video pembelajaran dan power point sangat efisien dan bermanfaat bagi para pengajar dan para siswa. Kemampuan pendidik dalam berkreasi dan berinovasi untuk membuat dan menyusun materi secara menarik dapat menjadi faktor utama, keberhasilan belajar siswa. Melalui media video pembelajaran dan power point minat belajar peserta didik dapat meningkat, kemauan pendidik untuk lebih berkreasi juga meningkat sehingga tingkat keberhasilan juga meningkat dalam pembelajaran Teknologi Informasi dan Komunikasi. Tujuan pembelajaran akan mudah dipahami siswa bila menggunakan media Video pembelajaran dan media Power Point. Dengan demikian dari hasil tulisan ini dapat disimpulkan bahwa Media Video Pembelajaran dan Power point dapat meningkatkan hasil pembelajaran TIK Kelas VII di SMPN 1 Gurah.

\section{DAFTAR PUSTAKA}

Aqib, Z. (2013). Model-model, media, dan strategi pembelajaran kontekstual (inovatif). Bandung: yrama widya.

Alphaomegaproperty. (2020). Pengertian Media Video Pembelajaran. https://alphaomegaproperty.co.id/pengertianmedia-video-pembelajaran/

Budiana, H. R., Sjafirah, N. A., \& Bakti, I. (2015). Pemanfaatan teknologi informasi dan komunikasi dalam pembelajaran bagi para guru SMPN 2 Kawali desa Citeureup kabupaten Ciamis. Dharmakarya, 4(1).

Busyaeri, A., Udin, T., \& Zaenudin, A. (2016). Pengaruh penggunaan video pembelajaran terhadap peningkatan hasil belajar mapel IPA di MIN Kroya Cirebon. Al Ibtida: Jurnal Pendidikan Guru MI, 3(1).

Ekayani, P. (2017). Pentingnya penggunaan media pembelajaran untuk meningkatkan prestasi belajar siswa. Jurnal Fakultas Ilmu Pendidikan Universitas Pendidikan Ganesha Singaraja, 2(1), 1-11.

Hujair, A. H. (2009). Sanaky, media pembelajaran.

Indrastyawati, C., Paidi, P., \& Ciptono, C. (2016). Pengembangan media pembelajaran sistem indera berbasis android untuk meningkatkan motivasi dan hasil belajar siswa SMA. Jurnal Pendidikan Biologi, 5(7), 50-56.

Komar, S. A. L. (2018). MANFAAT MEDIA POWERPOINT BAGI PENGAJIAN IBU-IBU MASJID FAJAR IKHLAS DI KELURAHAN SUMBEREJO KECAMATAN KEMILING KOTA BANDAR LAMPUNG (Doctoral dissertation, UIN Raden Intan Lampung).

Mabruroh, C., \& Dihan, F. N. (2015, July). Smartphone: antara kebutuhan dan e-lifestyle. In Seminar Nasional Informatika (SEMNASIF) (Vol. 1, No. 5).

Misbahudin, D., Rochman, C., Nasrudin, D., \& Solihati, I. (2018). Penggunaan Power Point Sebagai Media Pembelajaran: Efektifkah?. WaPFi (Wahana Pendidikan Fisika), 3(1), 43-48.

Palazon, M. (2000). The media and transformative learning. 
Science, Engineering, Education, and Development Studies (SEEDS): Conference Series Vol.4 no.2 (2020)

Riyana, C. (2007). Pedoman pengembangan media video. Jakarta: P3ai Upi, 2654-2552. Rusman, (2012). Model-model Pembelajaran : Mengembangkan Profesionalisme Guru. Jakarta: PT. Raja Grafindo Persada.

Smaldino, S. E., Russell, J. D., Heinich, R., \& Molenda, M. (2004). Instructional media and technologies for learning. Wingkel, Psikologi Pengajaran, Jakarta, Gramedia, 2004.

Yaumi, M. (2017). Media Pembelajaran: Pengertian, Fungsi, dan Urgensinya bagi Anak Milenial. 